\title{
An attempt at modelling the periphyton dynamics with artificial neural networks exemplified by the oxbow lake reopening study (The Słupia River, Northern Poland)
}

\author{
Krystian Obolewski*, Agnieszka Strzelczak** \\ *Department of Land Reclamation and Environmental Menagement, University of Warmia and Mazury, \\ Plac Łódzki 2, 10-756 Olsztyn, Poland \\ **Institute of Chemistry and Environmental Protection, Szczecin University of Technology, \\ Aleja Piastów 42, 71-065 Szczecin, Poland \\ corresponding author, e-mail: k_obolewski@op.pl
}

\begin{abstract}
An experiment was performed in the Osokowy Staw oxbow lake (the Słupia River, northern Poland). The old riverbed was reconnected with the riverine system and periphyton communities on nylon artificial substrate were surveyed before and after engineering works. Then, ANN (Artificial Neural Network) architectures were designed and trained in order to create models of interactions between 18 macrozooperiphyton, microzooperiphyton and phytoperiphyton taxa in the changing ecosystem. Calculations were performed using StatSoft Software Statistica 6.1 with the implemented neural network module.

Neural network models allowed a quantitative insight into periphyton dynamics and indicated trophic relationships, both predatoryprey and competitive. Thus, we see ANN as a good technique for modelling multidimensional, nonlinear relations between epiphytic organisms and as a promising method for creating overall models.
\end{abstract}

Key words: Artificial Neural Networks (ANN), periphyton dynamics and density, oxbow lake reopening, ecoengineering, artificial substrate, Pomerania.

\section{Introduction}

Modelling of periphyton dynamics presents some difficulties. Mostly they are caused by irregular changes in periphyton abundance, accompanied by high variety of epiphytic taxa and species. Ecological models of periphyton have been generally based on the deterministic approach and have predicted total periphyton biomass from physicochemical parameters (Dong et al. 2002; Buzzelli et al. 2000) in streams and rivers, taking into consideration also hydrological factors (Asaeda \& Son 2000, 2001; Dent \& Henry 1999). Additionally, attempts have been undertaken to create dynamic models of entire ecosystems with periphyton incorporated as one of the elements (Bartell et al. 1999; Yaung \& Sykes 1998). Deterministic models often give good results but they can be too general to be ap- plied to a specific case without a long calibration process. Moreover, they mostly approximate various processes with linear equations, ignoring many important factors, which cause non-linearity of the observed relationships.

Apart from deterministic methods, artificial neural networks (ANN) have also been applied, for instance to predict abundance of macroinvertebrates (Dedecker et al. 2004; Jorgensen et al. 2002). ANN is a relatively new modelling technique, useful in ecological modelling as a universal, approximating system with the ability to learn, adapt and generalize the acquired knowledge, especially applicable to multivariate data sets with non-linear relationships (Carling 1992; Fausett 1994; Tadeusiewicz 1993, 2001; Osowski 1996; Lek \& Guegan 1999).

The object of our study was an oxbow lake, as an ecosystem particularly endangered by eutrophication. River 
regulations, like cutting off old riverbeds, have been carried out since the end of the $19^{\text {th }}$ century. However, this type of engineering causes a number of unfavourable changes in fluvial ecosystems, mostly by limiting self-purification processes. In order to improve the water quality and to increase biodiversity, it is advisable to reconnect oxbow lakes with their riverine systems. As a result, the water inflow triggers off rearrangements of ecological formations. These changes also concern epiphytic organisms (periphyton) (Pieczyńska 1970), inhabiting various submerged substrates-both biotic and artificial ones.

So far, most of the studies on periphyton have been focused only on qualitative aspects of epiphytic assemblages in different types of waters (Piesik 1992; Szlauer et al. 2001). Their results indicate higher overgrowing of artificial than biotic substrates, which is caused by the lack of defensive reaction of the artificial substrate against overgrowing (Szlauer \& Szlauer 1999; Obolewski 2002). The overgrowing rate for periphyton organisms is determined by water flow (Obolewski 2003) and water physicochemistry (De Angelis et al. 1995). In re-opened oxbow lakes those factors bring about qualitative and quantitative rearrangements of periphyton communities, insufficiently described in literature.

Considering the above mentioned gaps in the knowledge - the lack of ecological models, which would include both epiphytic flora and fauna, and also insufficient research on periphyton in re-opened oxbow lakes- we chose the objective of this study. Our aim was to create preliminary ANN models of interactions between the discussed organisms in the ecosystem changing due to reopening. Applicability of the ANN technique to multidimensional problems with non-linear relationships between variables seemed to be a chance for successful modelling of such a complex issue.

\section{Study area}

The Słupia River has the total length of $138.6 \mathrm{~km}, 1623 \mathrm{~km}^{2}$ of the river basin area and flows through one large conurbation - Słupsk. Słupia flows into Słupsk forming a wide, unregulated riverbed. The investigated reservoir is located within the forest area called Lasek Południowy in Słupsk (Fig. 1). It is a right-bank, 80 years old oxbow lake with the area of 0.27 ha and the mean depth around $1 \mathrm{~m}$, located at $37,96 \mathrm{~km}$ of the Słupia River course.

\section{Materials and methods}

A preliminary survey of epiphytic organisms, inhabiting an artificial substrate in the researched old riverbed, started in November 1998 and in July 1999 the main investigation began. The experiment lasted until July 2002 in order to observe changes caused by reopening of the studied oxbow lake, which fell on the $13^{\text {th }}$ month of the experiment.

The artificial substrate, made of the potato-bag fabric, was being placed in water every month and fastened to floating polystyrene buoys and floats. In July 2000, land melioration works started, which aimed at reconnecting the cut-off oxbow lake with the proper riverbed. Pipe culverts, made of PCV tubes, were used for piping the sewage and were characterised by the following parameters: $\varnothing 160 \mathrm{~mm}$ and length of $3 \mathrm{~m}$.

In the closed oxbow lake 90 samples and after the reopening, 79 samples of epiphytic fauna and flora were taken. Artificial substrates with the area between 64 and $91 \mathrm{~cm}^{2}$ were cut out and preserved in situ using $8 \%$ formalin solution. In the laboratory, the size of substrate fragments was precisely measured and their area was calculated. The next stage was to brush off periphyton, rinse the removed material on a plankton net (mesh diameter: $60 \mu \mathrm{m})$ and transfer it into cylinders of different volume (50-100 $\mathrm{cm}^{3}$, depending on the material density). After making sure that the organisms were equally distributed in the water volume, three $1 \mathrm{~cm}^{3}$ subsamples were taken from each cylinder and transferred into a plankton counting chamber. The quantity of epiphytic flora was determined by recording its number in nine visual fields $\left(0.0157 \mathrm{~cm}^{2}\right.$ each field) under a microscope at 10 times magnification. The obtained results were referenced to the whole chamber area using the following formula:

$$
A_{A}=\frac{S_{k} \cdot N_{A}}{0.1413}
$$

where: $A_{A}$-abundance of epiphytic flora in a chamber [cells],

$S_{k}$ - overall chamber area $\left[\mathrm{cm}^{2}\right]$,

$N_{A}$ - the total of periphyton cells in the observed visual fields,

0.1413 - the observed chamber area $\left[\mathrm{cm}^{2}\right]$.

That procedure was repeated three times and the obtained number of epiphytic flora in chambers was summed up and recalculated into density, according to the formula:

$$
D_{P}=\frac{V_{C} \cdot A}{S_{s} \cdot n}
$$

where: $D_{p}-$ density of epiphytic flora $\left[\right.$ cells $\left./ \mathrm{m}^{2}\right]$,

$V_{c}^{p}-$ cylinder volume $\left[\mathrm{cm}^{3}\right]$

$A$ - the number of epiphytic flora individuals [cells],

$S_{s}$ - the substrate area, from which periphyton originates $\left[\mathrm{m}^{-2}\right]$,

$n-$ the number of subsamples of $1 \mathrm{~cm}^{3}$ volume. 


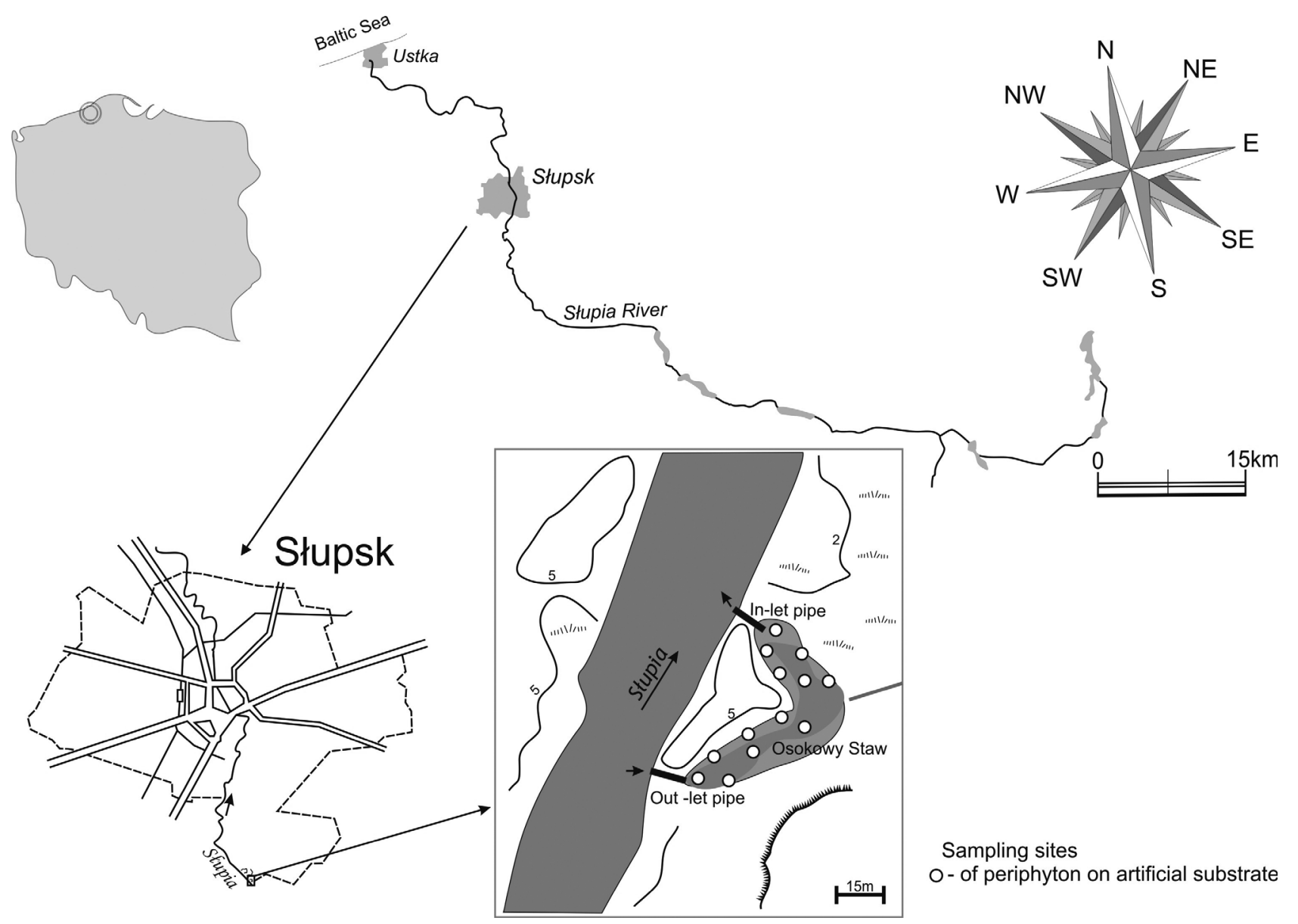

Figure 1. Location of the Osokowy Staw oxbow lake and distribution of sampling sites

Microzooperiphyton abundance was determined by recording the number of individuals in the whole plankton counting chamber, with linear division at 5 times magnification. The procedure was repeated three times and, after summing up, the results were recalculated into epiphytic microfauna density per $1 \mathrm{~m}^{2}$ substrate, using the formula (2).

Larger epiphytic fauna was selected from the samples, divided into individual taxa, counted and their number was referred to $1 \mathrm{~m}^{2}$ substrate according to the equation (2).

The comparison of average densities of the selected epiphytic flora and fauna taxa, before and after the reopening, are presented in Table 1.

\subsection{Data analyses}

The obtained hydrobiological data set was analysed using the artificial neural networks (ANN). Multi Layer Perceptions (MLP) were applied, which mathematically perform a stochastic approximation of multivariate functions (Osowski 1996). Densities of particular periphyton taxa
Table 1. Density of selected taxa before and after Osokowy Staw reopening

\begin{tabular}{|c|c|c|c|c|c|}
\hline \multirow[b]{2}{*}{ Period } & \multicolumn{5}{|c|}{ Density [indiv $\cdot 1000 / \mathrm{m}^{2}$ ] } \\
\hline & 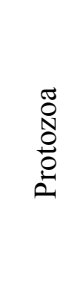 & 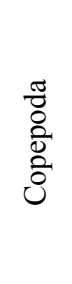 & 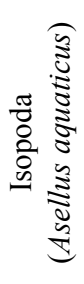 & 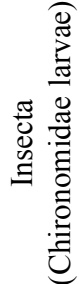 & 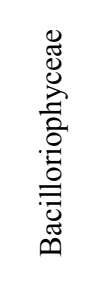 \\
\hline Before reopening & 458.2 & 8.1 & 0.2 & 1.5 & 1024.2 \\
\hline After reopening & 266.2 & 50.1 & 1.8 & 3.5 & 1899.9 \\
\hline
\end{tabular}

constitute output variables in this study, while the set of input variables included time (in months) and densities of the remaining periphyton taxa. In order to avoid redundation of input variables and to assure sufficient performance of neural network models, input taxa of the same group 
as an output taxon were substituted by the total densities of macrozooperiphyton, microzooperiphyton or phytoperiphyton.

Calculations were performed using StatSoft software Statistica 6.1 with the implemented neural network module (Lula 2000; Tadeusiewicz, 2001, 2004). Artificial neural networks were designed and tested by the Automatic Problem Solver. For the sake of a moderately large data set, all cases were divided with the bootstrap method into 3 subsets:

training (Tr) - used for training a neural network (98 cases);

verification (Ver) - used for verifying the network performance during training (50 cases);

testing (Te) - used for assessing the predictability and accuracy of a neural model by applying the data not presented during training and verification (cases remained after creating a training subset during bootstrap).

The choice criteria for the best neural network were as follow: a value of SD Ratio (a ratio between error standard deviation and standard deviation of experimental data), RMS (Root Mean Square) error of training, validation and testing subsets and a correlation coefficient between experimental data and values calculated by a network.

With the best neural models, interactions between particular taxa were assessed. Special emphasis was placed on sensitivity analysis, response plots and surfaces. Sensitivity analysis creates ranking of input variables and is based on calculations of error, when a given input variable is removed from a model. An error ratio for a complete model to the one with an ignored variable is the basis of ordering the variables according to their importance. A response graph is a response (output) as a function of one, selected input variable, or in other words - one-dimensional section through response surface in $\mathrm{N}$-dimensional space of input variables. As for a response surface graph, it is generated in the 3-dimensional space and represents a neural model output as a function of two selected input variables.

\section{Results}

Results of the performed analyses were neural models of interactions between individual periphyton taxa with reference to time. This study includes models with the best regression statistics, i.e. with SD Ratio $<0.7$ and Correlation coefficient $>0.6$. In the selected neural models characterised in Table 2, the output variables were: microzooperiphyton taxa Protozoa and Copepoda; macrozooperiphyton taxa Isopoda and Chironomidae larvae; the phytoperiphyton taxon Bacilloriophyceae. In all the cases, MLP networks were applied, trained with backpropagation algorithm (BP) and conjugant gradient descent algorithm (CGD).

Results of the sensitivity analysis, response graphs and surfaces for particular models are described below.

\section{Protozoa}

The total microzooperiphyton density had the strongest relationship with the density of Protozoa, while the time factor (reflecting the oxbow lake reopening) influenced the investigated taxon to a lesser extent (rank 10), (Tab. 3).

Table 2. Summary of periphyton neural network models

Network description: number of input variables: number of input neurons - number of neurons in hidden layers - number of output neurons: number of output variables. $\mathrm{Tr}$ - training subset; $\mathrm{Ve}$ - verification subset; $\mathrm{Te}$ - testing subset

\begin{tabular}{|c|c|c|c|c|c|}
\hline \multirow{3}{*}{ Output } & \multirow{3}{*}{ Neural model } & \multicolumn{4}{|c|}{ Performance } \\
\hline & & \multirow{2}{*}{ Parameter } & \multicolumn{3}{|c|}{ Subsets } \\
\hline & & & $\operatorname{Tr}$ & Ver & $\mathrm{Te}$ \\
\hline \multirow{2}{*}{ Protozoa } & \multirow{2}{*}{$\begin{array}{c}\text { MLP } \\
10: 10-5-1: 1\end{array}$} & SD Ratio & 0.403 & 0.361 & 0.462 \\
\hline & & Correlation & 0.921 & 0.951 & 0.891 \\
\hline \multirow{2}{*}{ Copepoda } & \multirow{2}{*}{$\begin{array}{c}\text { MLP } \\
10: 10-15-15-1: 1\end{array}$} & SD Ratio & 0.606 & 0.633 & 0.726 \\
\hline & & Correlation & 0.796 & 0.779 & 0.692 \\
\hline \multirow{2}{*}{$\begin{array}{l}\text { Isopoda } \\
\text { (Asellus aquaticus) }\end{array}$} & \multirow{2}{*}{$\begin{array}{c}\text { MLP } \\
14: 14-1-1: 1\end{array}$} & SD Ratio & 0.664 & 0.408 & 0.656 \\
\hline & & Correlation & 0.757 & 0.916 & 0.755 \\
\hline \multirow{2}{*}{$\begin{array}{l}\text { Insecta } \\
\text { (Chironomidae larvae) }\end{array}$} & \multirow{2}{*}{$\begin{array}{c}\text { MLP } \\
14: 14-1: 1\end{array}$} & SD Ratio & 0.502 & 0.593 & 0.647 \\
\hline & & Correlation & 0.866 & 0.820 & 0.792 \\
\hline \multirow{2}{*}{ Bacilloriophyceae } & \multirow{2}{*}{$\begin{array}{c}\text { MLP } \\
16: 16-4-7-1: 1\end{array}$} & SD Ratio & 0.139 & 0.060 & 0.175 \\
\hline & & Correlation & 0.990 & 0.998 & 0.988 \\
\hline
\end{tabular}


Table 3. Results of sensitivity analysis for microzooperiphyton taxa, Protozoa and Copepoda, neural network models

\begin{tabular}{|c|c|c|c|c|c|c|}
\hline Input & Output & Ratio & Rank & Output & Ratio & Rank \\
\hline Time & \multirow{10}{*}{$\begin{array}{l}\tilde{0} \\
N \\
0 \\
0 \\
0 \\
0\end{array}$} & 0.99 & 10 & \multirow{10}{*}{ 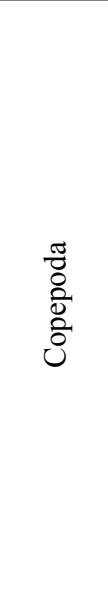 } & 1.34 & 1 \\
\hline Isopoda (Asellus aquaticus) & & 1.00 & 8 & & 1.07 & 4 \\
\hline Cordylophora caspia & & 1.25 & 2 & & 1.20 & 2 \\
\hline Podura aquatica & & 1.00 & 7 & & 1.04 & 6 \\
\hline Insecta (Chironomidae larvae) & & 1.01 & 5 & & 1.17 & 3 \\
\hline Gastropoda & & 1.00 & 6 & & 1.02 & 7 \\
\hline Bacilloriophyceae & & 1.02 & 4 & & 0.98 & 10 \\
\hline Cyanophyta & & 0.99 & 9 & & 1.06 & 5 \\
\hline Chlorophyta & & 1.02 & 3 & & 1.00 & 9 \\
\hline Microzooperiphyton & & 2.36 & 1 & & 1.01 & 8 \\
\hline
\end{tabular}

The reopening was accompanied by a slight increase in the density of Protozoa (Fig. 2).

The neural model also revealed a considerable interaction between Protozoa and Cordylophora caspia (Pall.) (rank 2) densities. According to Fig. 2, the increase in Cordylophora caspia abundance induces the decrease in the number of Protozoa individuals, significantly limiting its density and neutralizing the positive influence of the oxbow reopening on the discussed taxon.

\section{Copepoda}

Time was the most important variable influencing the density of Copepoda (Tab. 3). The neural model showed a clear, directly proportional relationship between those variables (Fig. 3a).

Additionally, strong non-linear interactions between densities of Copepoda and Cordylophora caspia (rank 2) were revealed (Fig. 3b). The response surface reflected two minima in Copepoda densities - one before the reopening, accompanied by high density of Cordylophora caspia, and another after reconnection, for low density of Cordylophora caspia.

Isopoda (Asellus aquaticus L.)

In the neural model for Isopoda (Asellus aquaticus), the total macrozooperiphyton density had the highest rank. Density of the discussed output taxon was also considerably influenced by time (rank 2) (Tab. 4). The reopening triggered off the increase in the density of Isopoda (Asellus aquaticus), according to Figure 4. The rest of input variables were characterised by low significance in the model (the ratio in sensitivity analyses close to 1 ).

Insecta (Chironomidae larvae)

Density of the total macrozooperiphyton had the strongest influence on the density of Chironomidae larvae
(Tab. 4). Reopening of the oxbow lake (time-rank 3) was accompanied by a small decrease in the density of the discussed taxon, which is represented in Figure 5. Just like for Isopoda (Asellus aquaticus), the rest of input variables had low significance in the model.

\section{Bacilloriophyceae}

Sensitivity analyses revealed a close connection between densities of Bacilloriophyceae and Chironomidae larvae (rank 1) (Tab. 5). A directly proportional relationship between the discussed taxa (Fig. 6b) neutralised the limiting influence of the oxbow lake reopening on Bacilloriophyceae (Fig. 6a).
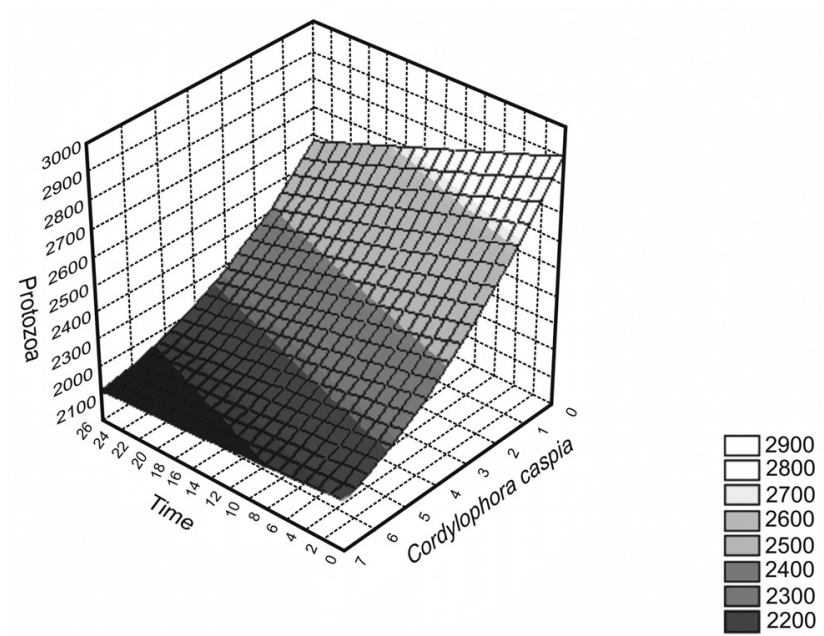

Figure 2. Response graph. Relations between Protozoa, time and Cordylophora caspia. Model MLP 10:10-5-1:1. Abundance unit: specimens $1000 / \mathrm{m}^{2}$; time unit: months 

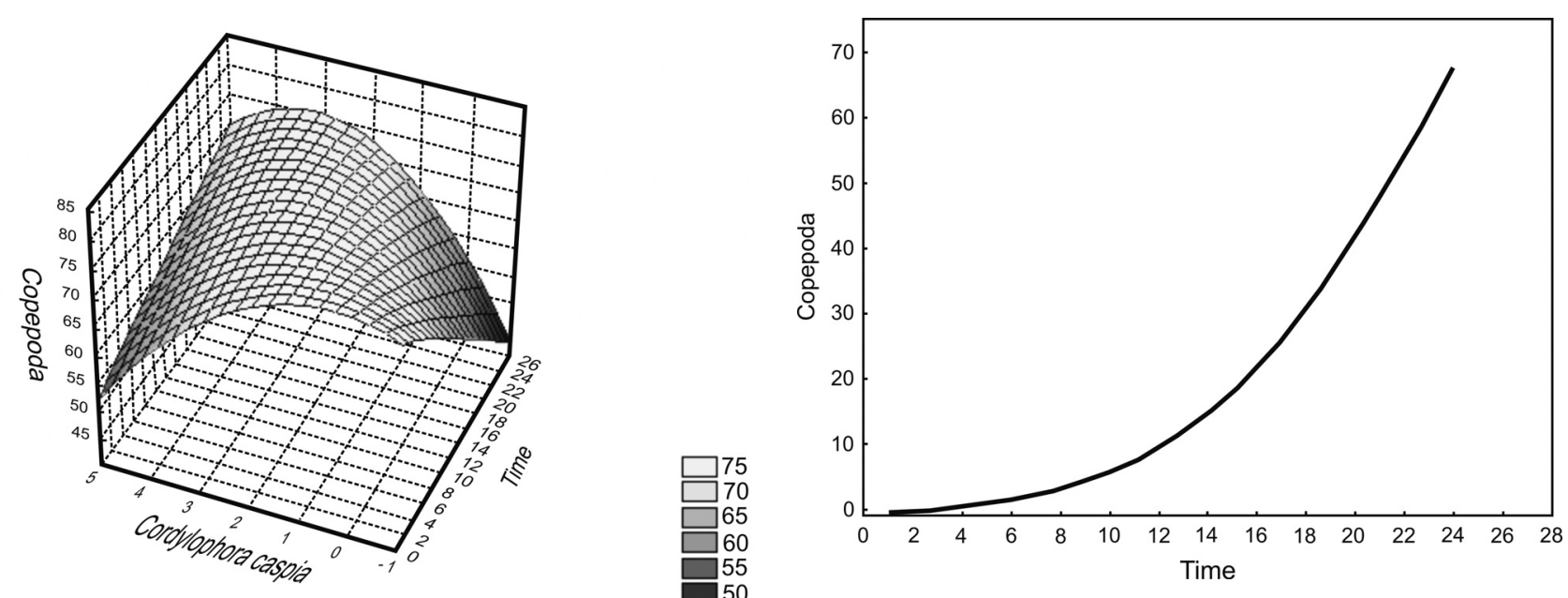

Figure 3. Response graphs: a - relations between Copepoda, time and Cordylophora caspia; $\mathrm{b}$ - model MLP 10:10-15-15-1:1. Abundance unit: specimens $1000 / \mathrm{m}^{2}$; time unit: months

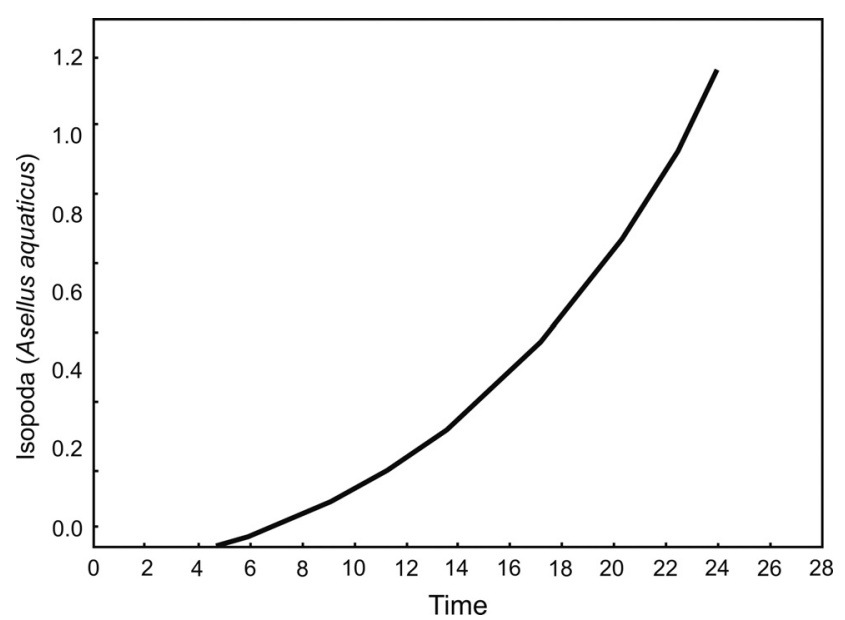

Figure 4. Response graph. Relations between Isopoda (Asellus aquaticus) and time. Neural network MLP 14:14-1-1:1. Abundance unit: specimens $1000 / \mathrm{m}^{2}$; time unit: months

\section{Discussion}

The experiment conducted in the Osokowy Staw oxbow lake allowed an interesting insight into qualitative and quantitative composition of periphyton communities over the time. Because the artificial substrate used in the study was made of nonbiodegradable steelon, impact of its chemical composition on the investigated flora and fauna was eliminated.

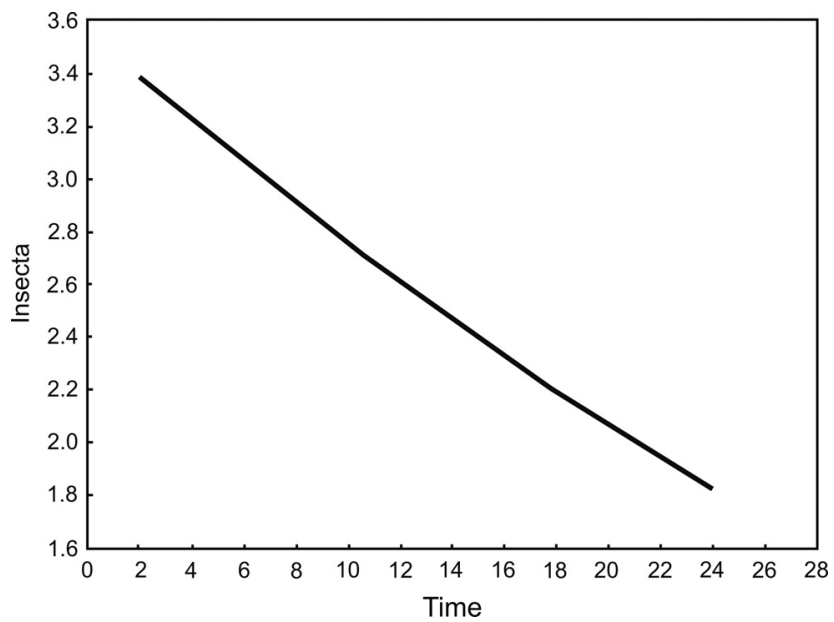

Figure 5. Response graph. Relations between Insecta (Chironomidae larvae) and time. Neural network MLP 14:14-1:1. Abundance unit: specimens $\cdot 1000 / \mathrm{m}^{2}$; time unit: months

The neural model revealed a strong competition between Protozoa and Cordylophora caspia (Fig. 2). Bacteriovorous Peritricha and herbivorous Testacea from Protozoa, compete with coelenterates represented by Cordylophora caspia. Trophic competition presented in the model presumably concerned the most numerous group, namely Peritricha. In the closed reservoir Osokowy Staw, the shore was intensively overgrown by rush flora and therefore was limited as a habitat for calanoids (Obolewski 2003). The 
Table 4. Results of sensitivity analysis for macrozooperiphyton taxa, Isopoda (Asellus aquaticus) and Insecta (Chironomidae larvae), neural network models

\begin{tabular}{|c|c|c|c|c|c|c|}
\hline Input & Output & Ratio & Rank & Output & Ratio & Rank \\
\hline Time & \multirow{14}{*}{ 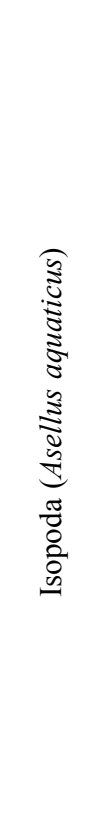 } & 1.20 & 2 & \multirow{14}{*}{ 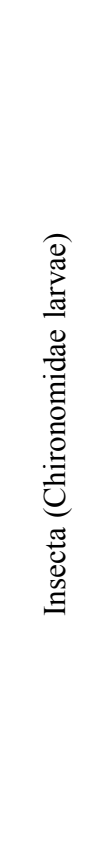 } & 1.03 & 3 \\
\hline Protozoa & & 1.00 & 8 & & 1.00 & 9 \\
\hline Rotatoria & & 1.00 & 10 & & 1.02 & 4 \\
\hline Turbellaria & & 1.00 & 13 & & 1.00 & 12 \\
\hline Nematoda & & 1.04 & 4 & & 1.01 & 6 \\
\hline Tardigrada & & 1.01 & 7 & & 1.00 & 7 \\
\hline Oligochaeta & & 1.01 & 6 & & 0.99 & 14 \\
\hline Cladocera & & 1.00 & 11 & & 1.06 & 2 \\
\hline Copepoda & & 1.00 & 9 & & 1.00 & 13 \\
\hline Hydrachnellae & & 1.02 & 5 & & 1.00 & 10 \\
\hline Bacilloriophyceae & & 1.06 & 3 & & 1.01 & 5 \\
\hline Cyanophyta & & 1.00 & 14 & & 1.00 & 8 \\
\hline Chlorophyta & & 1.00 & 12 & & 1.00 & 11 \\
\hline Macrozooperiphyton & & 1.46 & 1 & & 1.76 & 1 \\
\hline
\end{tabular}

reopening reduced aquatic vegetation, both floating and rushes, but also water flow was an important factor. Calanoids, as planktonic fauna, cannot resist water movement, therefore they were washed out from the reservoir. Cordylophora caspia is an alien species in Polish waters, so its occurrence and density is determined only by water thermics (Piesik 1992). Water temperature in the investigated oxbow lake was low, with the similar value before (on average $12^{\circ} \mathrm{C}$ ) and after the reopening (on average $11^{\circ} \mathrm{C}$ ) (Obolewski 2004) and did not favour the appearance of this calanoid species.

According to Figure 6b, a directly proportional relationship was observed between Bacilloriophyceae and Chironomidae larvae densities, while both of the taxa were poorly influenced by the reopening (Tab. 4 and 5, Fig. 5 and 6a). This effect can be explained in the following way. Some of the insects, like dragonflies, mayflies and stoneflies live in the water in the larval form only and take oxygen from the water, not from the air, breathing with gill appendages, tracheal gills or with the whole surface of their delicate epidermis. Some of these species occur in high abundances and, as the food for many other animals, are an important element in the organic matter cycle and conversion. Additionally, predatory species influence the size of populations of other aquatic organisms. Stoneflies
Plecoptera are insects inhabiting lotic, clear and oxygenated waters. All the juvenile larvae of stoneflies feed on dead organic matter, while older larvae graze on flora and fauna. Dragonflies, both larvae and adult forms, are predatory. Depending on the size of their bodies, larvae of dragonflies feed on aquatic microorganisms, crustaceans, flatworms, roundworms, aquatic insects, fry and amphibian larvae. Ephemeroptera larvae graze mainly on algae and fine organic matter, while Trichoptera larvae, depending on species, mainly on plants, small aquatic animals and plant debris. The reopening improved the water quality (higher oxygen concentration and higher amount of detritus) and favoured the density increase of Chironomidae larvae representatives (Obolewski 2004).

Phosphorus, nitrogen and silicon concentrations are important factors limiting the phytoperiphyton production (Havens et al. 1999). Riverine inflow reduces the nutrient concentration, which influences a number of epiphytic algae cells. At the same time, the N:P atomic ratio improves up to 8:1 (Allan 1998 after Hutchinson 1967). This constitutes a food supply for herbivorous Chironomidae larvae species, which in turn, constitute food for predatory organisms. Therefore, we can conclude that BacilloriophyceaeChironomidae larvae interactions, observed in the neural model, to a great extent are based on trophic relations. 

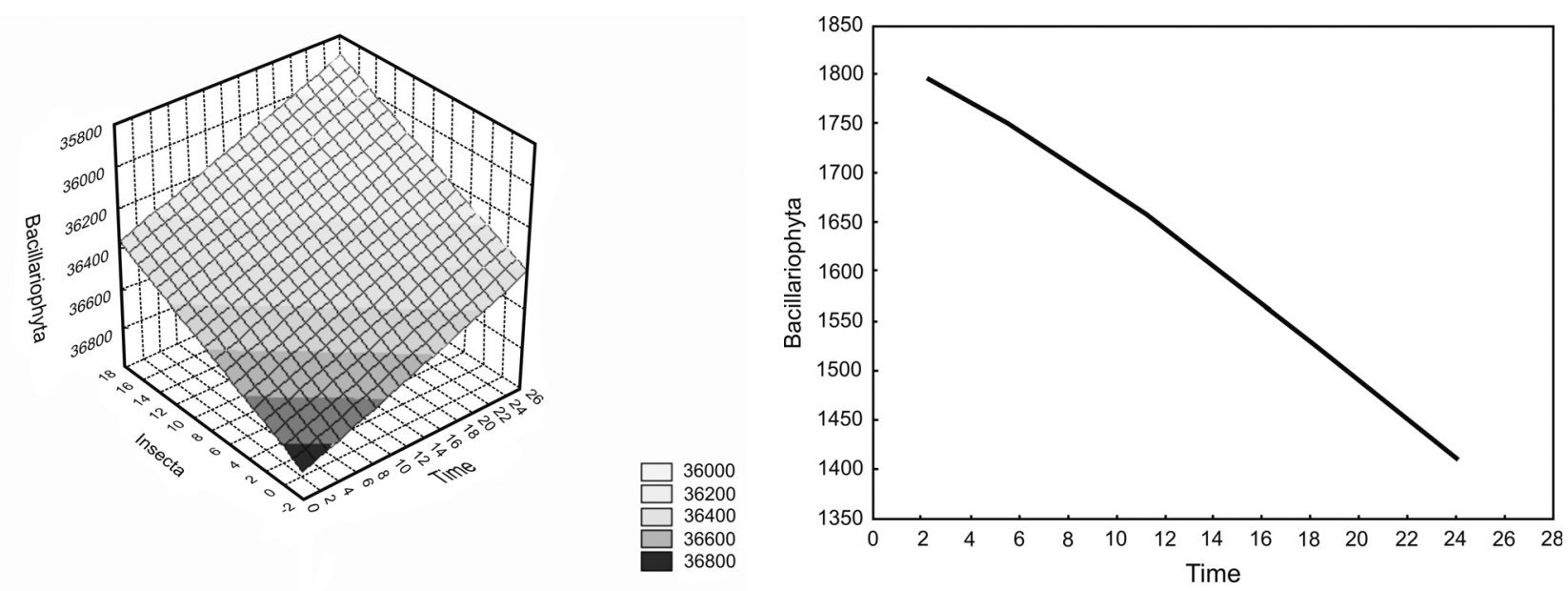

Figure 6. Response graphs: a - relations between Bacilloriophyceae, time and Insecta (Chironomidae larvae); b - neural network MLP 16:16-4-7-1:1. Abundance unit: specimens $1000 / \mathrm{m}^{2}$ for fauna and cells $1000 / \mathrm{m}^{2}$ for flora; time unit: months

According to Table 1, the density of Protozoa taxa decreased after reopening, while densities of the remaining analysed taxa increased. In lenitic waters (Osokowy Staw before reopening) the average density of algae was twice as low as on the artificial substrate during the first year after reopening. Restoration of the oxbow lake by the forced water flow induced the improvement of light and oxygen conditions and the water quality, which favoured the appearance of environmentally sensitive species. Comparison of periphyton average densities does not indicate which group of organisms was influenced to the largest extent. The applied neural models not only confirmed the general trends in changes of the analysed taxa densities but also allowed an interesting insight into periphyton dynamics.

Neural models revealed that the oxbow lake reopening influenced mostly Isopoda and Copepoda taxa (Tab. 3 and 4, Fig. 3 and 4). This effect is connected with disappearance of floating flora (Stratiotes aloides L.) from Osokowy Staw, thus with the improvement in light conditions. As a result, the abundance of diatoms increased considerably, which is a typical situation (Allan 1998, after Patrick 1961). Diatom food supply favoured intensive inhabitation of the ecological niche by herbivorous species like Harpacticoida (dominant on artificial substrates in most of the lakes and rivers) and Asellus aquaticus (Piesik \& Obolewski 2004). Before reopening, Asellus aquaticus inhabited the bottom but its presence was limited to a narrow, coastal zone. After reconnection, the additional substrate (plants overgrown by algae) created favourable conditions for Asellus aquaticus expansion and induced almost 2000-times increase in its density (Obolewski 2003). The discussed taxon, as an element of the food chain, eliminates algae and epiphytic microfauna from the substrate.
Table 5. Results of sensitivity analysis for a phytoperiphyton taxon, Bacilloriophyceae, a neural network model

\begin{tabular}{|c|c|c|c|}
\hline Input & Output & Ratio & Rank \\
\hline Time & \multirow{16}{*}{ 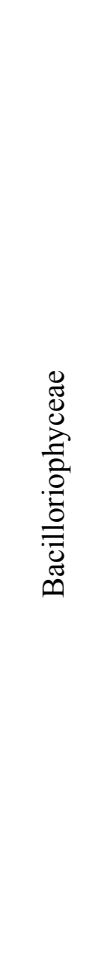 } & 1.03 & 3 \\
\hline Protozoa & & 1.00 & 9 \\
\hline Rotatoria & & 1.02 & 4 \\
\hline Turbellaria & & 1.00 & 12 \\
\hline Nematoda & & 1.01 & 6 \\
\hline Tardigrada & & 1.00 & 7 \\
\hline Oligochaeta & & 0.99 & 14 \\
\hline Cladocera & & 1.06 & 2 \\
\hline Copepoda & & 1.00 & 13 \\
\hline Hydrachnellae & & 1.00 & 10 \\
\hline Isopoda (Asellus aquaticus) & & 1.01 & 5 \\
\hline Cordylophora caspia & & 1.00 & 8 \\
\hline Podura aquatica & & 1.00 & 11 \\
\hline Insecta (Chironomidae larvae) & & 1.76 & 1 \\
\hline Gastropoda & & 1.03 & 3 \\
\hline Phytoperiphyton & & 1.00 & 9 \\
\hline
\end{tabular}


With the improvement of light and oxygen conditions, caused by riverine water inflow, the increase in algae and Asellus aquaticus abundance occurred. Asellus aquaticus feeds on coarse particulate organic matter (Allan 1998), which was abundantly accumulated in Osokowy Staw and the riverine-water inflow was an additional supply.

A slight decrease in the density, induced by the reopening, was observed for Protozoa (Tab. 3, Fig. 2). This taxon occurs mostly in highly polluted waters, where rich, bacterial food supply exists. Therefore, the riverine-water flow after reconnection must have reduced bacteria abundance, which, in turn, decreased Protozoa density (Eadie et al. 2004; Matz \& Kjelleberg 2005).

\section{Conclusions}

Artificial neural networks, applied in this study, allowed a quantitative insight into interactions between the selected taxa of epiphytic organisms inhabiting the Osokowy Staw oxbow lake, indicating trophic relationships, both predatory-prey and competitive. A strong competition between Protozoa (mainly Peritricha and Testacea) and Cordylophora caspia was revealed, while a directly proportional relationship was observed between Bacilloriophyceae and Chironomidae larvae, to a great extent based on trophic relationships. The obtained neural network models showed that the density of Protozoa taxa decreased after the reopening, while the densities of the remaining taxa increased. The oxbow lake reopening influenced Isopoda and Copepoda taxa the most, which was connected with the disappearance of floating flora (Stratiotes aloides L.) from Osokowy Staw, thus improvement in light conditions.

High performance of the models was obtained even though the time factor, reflecting changes in the ecosystem due to the lake reopening, was taken into account. The possibility of analysing these issues at the same time and successful explanation of the revealed periphyton dynamics, make artificial neural networks a promising tool for modelling this ecological formation. The next step would be to create an overall model by including also environmental parameters.

\section{Acknowledgments}

This scientific study was financed by educational funds, as a research project no. PBZ/MNiSW/07/2006/07.

\section{References}

Allan D. J., 1998, Ekologia wód płynących [Ecology of lotic waters], PWN, Warszawa.
Asaeda T. \& Son T. H., 2000, Spatial structure and populations of a periphyton community: a model and verification, Ecol. Model. 133: 195-207.

Asaeda T. \& Son D. H., 2001, A model of the development of a periphyton community resource and flow dynamics, Ecol. Model. 137: 61-75.

Bartell S. M., Lefebvre G., Kaminski G., Carreau M. \& Campbell K. R., 1999, An ecosystem model for assessing ecological risks in Québec rivers, lakes, and reservoirs, Ecol. Model. 24: 43-67.

Buzzelli C. P., Childers D. L., Dong Q. \& Jones R. D., 2000, Simulation of periphyton phosphorus dynamics in Everglades National Park, Ecol. Model. 134: $103-115$.

Carling A., 1992, Introducing Neural Networks, Sigma Press, Wilmslow, UK.

DeAngelis D. L., Loreau M., Neergaard D. \& Mulholland P., 1995, Modelling nutrient-periphyton dynamics in streams: the importance of transient storage zones, Ecol. Model. 80: 149-160.

Dedecker A. P., Goethals P. L. M., Gabriels W. \& De Pauw N., 2004, Optimization of artificial neural network (ANN) model design for prediction of macroinvertebrates in the Zwalm river basin (Flanders, Belgium), Ecol. Model. 174: 161-173.

Dent C. L. \& Henry J. C., 1999, Modelling nutrient-periphyton dynamics in streams with surface-subsurface exchange, Ecol. Model. 122: 97-116.

Dong Q., McCormick P. V., Sklar F. H. \& DeAngelis D. L., 2002, Structural instability, multiple stable states and hysteresis in periphyton driven by phosphorus enrichment in the Everglades, Theoret. Pop. Biol. 61: 1-13.

Eadie J. M., Hobson P. N. \& Mann S. O., 2004, A relationship between some bacteria, protozoa and diet in early weaned calves, Nature 183: 624-625.

Fausett L., 1994, Fundamentals of Neural Networks, Prentice Hall, New York.

Havens K. E., East T. L., Rodusky A. J. \& Sharfstein B., 1999, Littoral periphyton responses to nitrogen and phosphorus: an experimental study in a subtropical lake, Aquat. Bot. 63: 267-290.

Hutchinson G. E., 1967, A Treatise on Limnology. Vol. 2, Introduction to Lake Biology and the Limnoplankton, John Wilez \& Sons, New York.

Jorgensen S. E., Verdonschot P. \& Lek S., 2002, Explanation of the observed structure of functional feeding groups of aquatic macro-invertebrates by an ecological model at the maximum energy principle, Ecol. Model. 158: $223-231$.

Lek S. \& Guegan J. F., 1999, Artificial neural networks as a tool in ecological modelling, an introduction, Ecol. Model. 120: 65-73.

Lula P., 2000, Wybrane możliwości zastosowań sieci neuronowych programu STATISTICA Neural Networks 
[Selected applications of artificial neural networks in STATISTICA Neural Networks software], StatSoft Polska, Kraków.

Matz C. \& Kjelleberg S., 2005, Off the hook - how bacteria survive protozoan grazing, Trends Microbiol., 13: 302-307.

Obolewski K., 2002, Organizmy poroślowe (perifiton) zasiedlające trzcinę Phragmites australis i pałkę Typha latifolia oraz sztuczne podłoże w pomorskim jeziorze Lubowidzkim - badania wstępne [Epiphytic organisms (periphyton) inhabiting reed Phragmites australis, broadleaf cattail Typha latifolia and artificial substrate in the Pomeranian Lubowidzkie Lake- preliminary study], Słupskie Prace Przyrodn., Limnologia 1: $71-82$.

Obolewski K., 2003, Reakcje perifitonu na udrożnienie starorzecza rzeki Stupi [Reaction of periphyton on reopening of the oxbow lake on the Słupia River], $\mathrm{PhD}$ Dis. PAP, Słupsk: 202.

Obolewski K., 2004, Chemical changes in the water column of Osokowy Staw oxbow lake of the Stupia River as a result of its opening, [in:] Z. Galbács (ed.), Analytical and Environmental Problems, Szeged: 111-115.

Osowski S., 1996, Sieci neuronowe w ujęciu algorytmicznym [Artificial neural networks in algorithmic depiction], WNT, Warszawa.

Patrick R., 1961, A study of the numbers and kinds of species found in rivers in eastern United States, Proc. Acad. Nat. Sci., Philadelphia 113: 215-258.

Pieczyńska E., 1970, Peryfiton jako pokarm zwierząt wodnych (metody badań) [Periphyton as food for aquatic animals (methods of investigation)], Wiadom. Ekol. 16: $133-144$.
Piesik Z., 1992, Biologia i ekologiczna rola organizmów poroślowych (perifiton) zasiedlających sztuczne podłoża w różnych typach wód [Biology and ecological role of epiphytic organisms (periphyton) inhabiting artificial substrate in various types of waters], US, Rozp. Stud., Słupsk: 122-263.

Piesik Z. \& Obolewski K., 2004, Fouling fauna (zooperiphyton) inhabiting reed Phragmites australis (CAV.) Trin. ex STEUD. in Lake Wicko Przymorskie, Balt. Coast. Zone 8: 81-94.

Szlauer L. \& Szlauer B., 1999, Periphyton community on polyethylene sheets after a few years of exposure in a lake, Pol. Arch. Hydrobiol. 46 (3-4): 339-334.

Szlauer L., Szlauer B. \& Szlauer-Łukaszewska A., 2001, Niekonwencjonalne metody oczyszczania wód [Unconventional methods of water purification], Nauka - Gospodarka, A. R., Szczecin: 23.

Tadeusiewicz R., 1993, Sieci neuronowe [Artificial neural networks], Akademicka Oficyna Wydawnicza, Warszawa.

Tadeusiewicz R., 2001, Wprowadzenie do sieci neuronowych [Introduction to artificial neural networks], Statsoft Polska, Kraków.

Tadeusiewicz R., 2004, Wprowadzenie do praktyki stosowania sieci neuronowych [Introduction to practical application of artificial neural networks], URL: http:// www.statsoft.pl.

Yang M. D. \& Sykes R. M., 1998, Trophic-dynamic modelling in a shallow eutrophic river ecosystem, Ecol. Model. 105: 129-139. 